\title{
Author Index Volume 19 (1999)
}

The issue number is given in front of the page numbers.

Blom, D., Skills of Knowledge and Information Managers - are curricula up-to-date (enough)?

(1) $3-6$

Borgman, C.L., Books, bytes, and behavior: Rethinking scholarly communication for a global information infrastructure

(2) $117-121$

Cawkell, T., Internet futures: information capacity and information retrieval

(2) $107-110$

Cawkell, T., Informatics observed

Collier, M., Blue sky to green grass: The LIC's research strategy

Dixon, B., What are science journalists for?

(4) $237-264$

(2) $147-152$

(2) $75-81$

Elias, A.W., Acknowledgements

(3) $\quad 173$

Evers, P., Abstract: The Integration of Internal and External Information resources in a Corporate KIM

(1) 55

Garfield, E., From the World Brain to the Informatorium

(2) $99-105$

Goh, A., see Kok, Y.H.

(4) 265-276

Halm, J. van, Editorial: Proceedings of the First Knowledge \& Information Management Conference (KIM'99) held in Maastricht, 4-5 March 1999

Halm, J. van, The digital library as access management facilitator

Halm, J. van, Knowledge and information management (KIM'21)

Hauer, M., Three thousand years of knowledge management: What can we learn from science?

Herman, R., Science as she is spoken: authentic voices or public relations

Hoffman, D., Users and their use of information

Hoffmann, S., Virtual Academies for companies and educational institutions

Hoffstaedter, P. and K. Kohn, Telos Language Partner: Multimedia language learning, authoring and customisation

Holaday, D., see Kok, Y.H.

(1) $1-2$

(4) 299-303

(4) $305-306$

(1) $37-44$

(2) $83-88$

(3) $195-198$

(1) $33-36$

(4) $277-287$

(4) $265-276$

Jacobs, R., Abstract: Content management and NewsCircle

(1) 47

Koenig, M.E.D., Education for Knowledge Management

(1) $17-31$

Kohn, K., see Hoffstaedter, P.

Kok, Y.H., A. Goh and D. Holaday, Agenda: A tool for agenda setting research

(4) $277-287$

(4) $265-276$

Law, D., The British Library and the impact of research

(2) $127-133$

Lennon, D., Abstract: How are Information and Services Providers going to cope with the changing information needs? 
Luther, J., Whence document delivery?

(3) 207-208

Luther, J., New horizons

(3) 209-210

Mackenzie Owen, J., Knowledge management and the information professional

(1) $7-16$

Mahon, B., IT - big I and small T or big T and small I; an assessment

(2) $93-98$

Meadows, J., Where do we go from here?

Muldowney, S., see Wade, V.P.

(2) $165-169$

(3) $211-225$

Nelke, M., The role of the corporate library in the knowledge management process

(1) $49-54$

Oppenheim, C., Who needs a National Information Policy?

(2) $143-146$

Page, G., The future: will it work?

Pye, J., Perspectives of ICT in professional development and education

(2) $157-161$

(4) $307-312$

Rowley, J., Towards a consumer perspective on information behaviour research

(4) 289-298

Russon, D., Can research shape the future of the British Library?

(2) $135-137$

Tolen, F.A.L., Knowledge management: a practical approach

(1) $57-61$

Wade, V.P. and S. Muldowney, Experience representing, integrating and automating telecom business processes in a workflow engine environment

Wolfendale, A., From solar radiation to informatic gyration - the travels of an astronomically talented polymath

(3) $211-225$

(2) $71-72$ 